EESTI NSV TEADUSTE AKADEEMIA TOIMETISED 1953. II k., nr. 2 ИЗВЕСТИЯ АКАДЕМИИ НАУК ЭСТОНСКОИ ССР 1953. ТоМ II, N 2

\title{
ОБ ОПРЕДЕЛЕНИИ СМОЛИСТЫХ ВЕЩЕСТВ В ЗАДЫМЛЕННОМ ВОЗДУХЕ
}

\author{
н. М. ТомСон, \\ действительный член Академия наук Эстонской ССР
}

При сжигании сланца в обыкновенных топках образуется большое колнчество продуктов неполного сгорания - сажи, дыма, смолистых веществ, окиси углерода и т. д. - вследствие содержания в сланце сравнительно большого количества летучих углеводородов (до $70 \%$, тогда как бурый уголь содержит около $30 \%$, а антрацит только около $5 \%$ летучих углеводородов).

Образование дыма при прочих равных условиях зависит от вида топлива и наряду с этим от способа сжигания. Неполное сгорание топлива обусловлено низкой температурой, недостатком кислорода воздуха и неполным перемешиванием газов горения.

На крупных электростанциях сланец сжитается в пылевидном состоянии, причем прощесс горения регулируется путем подачи воздуха такнм образом, чтобы продукты неполного сгорания не могли образовываться. В этом случае вместе с отходящими газами в атмосферу выбрасывается только летучая зола, а дымовой факел имеет серовато-белый цвет. Ле тучая зола улавливается циклонами, мультишиклонами, электрофильграми или пенными (водяными) фнльтрами.

Дым н сажа не могут улавливаться этими фильтрами, так как частицы дыма имеют размеры меньше 0,001 мм, в то время как указанные фильтры улавливают только частицы размером болыше 0,005 мм. Частицы дыма, покрытые смолистыми веществами, являясь гидрофобными, не улавливаются никакими мокрыми фильтрами. Поэтому фильтры не являются исчерпывающим средством предохранения воздуха от загряз. нения, так как они не улавливают пылинки меньше 0,005 мм, которые способны проникать в легкие при дыхании.

Для малых котелен необходимо рекомендовать бездымный двухступенчатый способ сжигания, при котором в первой ступени сланец газифицируется, а во второй ступени пронсходит сгорание газа путем регулирования подачи воздуха. Осуществленный Институтом энергетики АН ЭССР двухступенчатый метод сжитания сланца обеспечивает полное сгорание.

Согласно закону от 29 мая 1949 года об охране чистоты атмосферного воздуха в населенных местах на Министерство здравоохранения возлагается контроль за чистотой атмосферного воздуха в городах. Для осуществления контроля необходимо установить предельно допустимые концентрации загрязняющих воздух вешеств и выработать метод их определения. 
В настоящей работе предлагается метод определения смолистых веществ в атмосферном воздухе. Контроль за загрязненнем воздуха целесообразно вести по смолистым веществам, так как последние являются наиболее вредными составными частями продуктов неполного сгорания топлива.

Другие составные части продуктов неполного сгорания - дым и сажа обыкновенно определяются путем просасывания воздуха через фильтровальную бумагу, заключенную в патрон. На фильтровальной бумаге получается черное пятно, ннтенсивность которого сравнивается со стандартом. Вместе с сажей на фильтровальную бумагу оседает также находящаяся в воздухе минеральная и органическая пыль, которая обычно имеет светлые оттенки и поэтому затрудняет определение дыма и сажи. Окись же углерода под влиянием атмосферных условий быстро окисляется до углекислоты и поэтому далеко не распространяется и долго в воздухе не сохраняется.

Смолистые вещества по способу образования и по составу похожи на сланцевые масла и смолы, образующиеся при сухой перегонке. В состав смолистых веществ входит несколько десятков разнообразных легких и тяжелых углеводородов, органических кислот, альдегидов, кетонов и пр., действующих раздражающе и токсически на организм. В смолистых веществах, выделенных Институтом экспериментальной и клинической медицины АН ӘССР в 1949 году в городе Таллине из атмосферного воздуха вблизи электростанции, работающей на сланцевом топливе, был обнаружен 3,4-бензпирен, который обладает канцерогенным действием ${ }^{1}$. Только при достаточно малой конщентрации смолнстых веществ в воздухе нельзя говорить о каком-либо заметном раздражающем действни нх.

Предлагаемый метод определения смолистых веществ в задымленном воздухе заключается в просасывании воздуха через органические растворители, напрнмер через спирт или бензол, обладающие способностью растворять смолистые вещества и позволяющие, таким образом, улавливать нх. В поглотитель типа Петри наливается 5 куб. см спирта или 10 куб. см бензола, предварительно проверенных на отсутствие в них смолистых веществ путем люминесцентного анализа и очищенных путем перегонки. Воздух через поглотитель просасывается каким-либо аспиратором, например водяным, состоящим из двух $2-5$-литровых бутылей. Экспериментально установлено, что достаточно прососать 25 литров воздуха со скоростью 0,5 литров в минуту, т. е. в течение 50 минут.

Определение концентрации смолистых веществ в поглотительном растворе пронзводится методом люминесцентнопо анализа, который состоит в следуюшем. В затемненной комнате проба освещается фильтрованным ультрафиолетовым светом (кварцевая лампа ПРК-4 со светонепроницаемым кожухом и с ультрафнолетовым фильтром из черного кобальтникелевого стекла, пропускающего ультрафиолетовые лучи и не пропускающего видимые световые лучи). В фильтрованном ультрафиолетовом свете проба, содержащая смолистые вещества, люминесцирует синефиолетовым светом. Концентращия смолистых веществ в воздухе определяется по интенсивности наблюдаемого люминесцентного свечения, путем сравнения со стандартами, которые должны быть приготовлены предварительно. Для этопо смолистые вещества путем аспирации соби раются в течение многих часов. Выпариванием органического растворителя получается чистое смолнстое вещество, из которого и готовятся стандарты растворением определенного весового колнчества их (доли мг)

Нзвестия АН ЭССР, 1952, № 3, стр. 31 . 
в спирте. Стандарты должны готовиться для каждого города особо, так как топливо и условия горения в разньх городах могут быть неодинаковыми и поэтому состав и качество смолистых веществ могут быть также разными.

При относительно чистом воздухе в городе, вдали от дымяцнх труб и среди зеленых насаждений, при просасывании 25 литров атмосферного воздуха получается едва заметное голубое овечение, а в наиболее задымленном месте те же 25 литров воздуха дают весьма интенсивное синефиолетовое свечение пробы.

При просасывании 25 литров воздуха через 10 куб. см бепзола последний нспаряется н к концу аспирации его остается около 2 куб. см, а из 5 куб. см спирта остается около 4 куб. см. Для сравнимости результатов оставшийся поглотительный раствор во всех пробах должен быть доведен до одинакового количества выпариванием или же добавлением растворителя, если данное количество недостаточно для удобного наблюдения люминесцентного свечения.

Отобранные описанным способом пробы могут непосредственно служить для оценки задымленности атмосферного воздуха. Кроме того, эти же пробы могут быть подвергнуты флюоресцентному спектральному анализу для количественного определения содержания раздражающих химнческих веществ (3,4-бензпирена).

Предлагаемый метод позволяет определить в атмосферном воздухе смолистые вещества, наиболее вредные составные части задымленного воздуха, что является дальнейшим шагом в борьбе за чнстоту воздуха, за создание наиболее благоприятных условий труда и быта для граждан сощиалистического общества.

Работа выполнена в Ленинградском научно-исследовательском санитарно-гигиеническом институте при участии научного сотрудника В. В. Пресновой. 